\title{
UNUSUAL CELLULAR FATTY ACIDS AND DISTINCTIVE ULTRASTRUCTURE IN A NEW SPIRAL BACTERIUM (CAMPYLOBACTER PYLORIDIS) FROM THE HUMAN GASTRIC MUCOSA
}

\author{
C. S. Goodwin, R. K. McCulloch, J. A. Armstrong* and S. H. WeE* \\ Departments of Microbiology and *Pathology, Royal Perth Hospital, Box X 2213, \\ G.P.O., Perth, Western Australia, 6001
}

\begin{abstract}
SUMmaRY. Spiral bacteria, named Campylobacter pyloridis, were obtained from endoscopic biopsies of the gastric antrum of 14 patients with active chronic gastritis. Methyl esters of their cellular fatty acids were prepared by acid-catalysed transmethylation of whole cells. Their major fatty acids were tetradecanoic acid (14:0) and cis-9,10-methyleneoctadecanoic acid $(19: 0 \Delta)$, with a very small amount of hexadecanoic acid (16:0). This is markedly different from the fatty acids of other Campylobacter sp. whose major fatty acids are hexadecanoic, octadecenoic (18:1) and hexadecenoic acids (16:1). This is also different from other enterobacteria.

Thin-section electronmicroscopy of gastric mucosal biopsies, and negative staining of cultured $C$. pyloridis, revealed features that differ from those of other campylobacters so far studied. C. pyloridis has a smooth not a rugose surface and multiple unipolar flagella of the sheathed type, each with a terminal bulb. Flagellar sheaths were in continuity with the unit membrane of the outer cell wall.

The proposed species $C$. pyloridis does not belong among the spirochaetes and its DNA composition is incompatible with membership of the genera Spirillum or Vibrio but is compatible with Campylobacter. Thus $C$. pyloridis is either an atypical member of the genus Campylobacter, the limits of which may have to be redefined to accommodate the new species, or a representative of a new genus.
\end{abstract}

\section{INTRODUCTION}

Spiral bacteria have been seen in close association with the epithelium of the gastric antral mucosa in patients with active chronic gastritis and, sometimes, peptic ulcer (Warren, 1983; Marshall and Warren, 1984; Rollason et al., 1984). In 1982, in the Royal Perth Hospital, Western Australia, campylobacter-like organisms were cultured from 11 endoscopic biopsies of the gastric antrum (Marshall, 1983) and the name Campylobacter pyloridis has been proposed (Marshall et al., 1984). C. pyloridis has also been cultured by other workers (Eldridge et al., 1984; McNulty and Watson, 1984). Its 
cultural characteristics and antibiotic sensitivities are somewhat different from those of other Campylobacter sp. (Marshall et al., 1984).

It is now accepted that the cellular fatty acid composition of bacteria is important taxonomically (Lechevalier, 1977; Lambert et al., 1983). In this study we have, therefore, determined the cellular fatty acids of $C$. pyloridis and some significant features of its ultrastructure are also reported.

\section{MATERIALS AND METHODS}

Patients. Some of the isolates of C. pyloridis for the present study were obtained from a series of 100 patients studied by Marshall et al. (1984) and the other isolates were obtained during April, 1984. Patients at the Gastroenterology Clinic in the Royal Perth Hospital who complained of symptoms suggestive of gastritis or peptic ulcer were subjected to endoscopy and two biopsies were obtained from the gastric antral mucosa. One biopsy was divided for histological and ultrastructural studies and the histopathological features have been reported elsewhere (Marshall and Warren, 1984). The second biopsy was placed in $0.5 \mathrm{ml}$ of a $20 \%$ glucose solution, to prevent possible dissolution of the mucus layer under which the bacteria adhere to the mucosa; these specimens were processed within $2 \mathrm{~h}$ of collection.

Isolates. A corner of the biopsy was cut off and a film was stained by Gram's method; the remainder was ground in $0.3 \mathrm{ml}$ of $20 \%$ glucose with a ground-glass grinder. One drop of the suspension was inoculated on to Brain-Heart Infusion Agar (Oxoid) containing horse blood $7 \%$, IsoVitaleX (BBL, Microbiology Systems) $1.0 \%$, vancomycin $3 \mathrm{mg} / \mathrm{L}$, nalidixic acid $10 \mathrm{mg} / \mathrm{L}$, and trimethoprim $5 \mathrm{mg} / \mathrm{L}$. The plates were incubated at $37^{\circ} \mathrm{C}$ in an anaerobic jar which was evacuated to $530 \mathrm{~mm} \mathrm{Hg}$ and refilled with an anaerobic gas mixture composed of $\mathrm{CO}_{2} 10 \%, \mathrm{H}_{2}$ $10 \%, \mathrm{~N}_{2} 80 \%$, which resulted in a final gas composition of $\mathrm{O}_{2} 5 \%, \mathrm{CO}_{2} 8 \%, \mathrm{H}_{2} 8 \%$ and $\mathrm{N}_{2} 82 \%$. Growth usually appeared as 0.5 - $\mathrm{mm}$ diameter translucent colonies after incubation for 3 days.

Gas liquid chromatography. Fourteen isolates including two strains deposited in the National Collection of Type Cultures (NCTC nos 11637 and 11638), were cultured on heated-blood agar without antibiotics for 4 days. Bacteria were harvested and washed twice in phosphate-buffered saline $\left(p \mathrm{H} \mathrm{7.3)}\right.$ and centrifuged at $5 \times 10^{3} \mathrm{~g}$ for $10 \mathrm{~min}$. The cells were dried under a stream of nitrogen. Cellular fatty acids were methylated with $2 \mathrm{ml}$ of a $4 \%$ solution of sulphuric acid in methanol at $78^{\circ} \mathrm{C}$ for $15 \mathrm{~min}$. Saturated $\mathrm{NaCl}$ was added, and the methyl esters were extracted with $2 \mathrm{ml}$ of a $1: 4$ chloroform: hexane mixture. The extract was concentrated to $0.2 \mathrm{ml}$ under a stream of nitrogen. The fatty acid methyl esters were analysed on a Packard 437 Gas-Liquid Chromatograph with a Flame Ionisation Detector and a Packard 604 Recording Data Processor. Separation was achieved with a $2 \mathrm{~m} \times 4 \mathrm{~mm}$ glass column packed with $10 \%$ Alltech $\mathrm{CS}-5$ on a chromosorb W-AW with the injector at $250^{\circ} \mathrm{C}$, the detector at $270^{\circ} \mathrm{C}$ and the oven temperature held at $195^{\circ} \mathrm{C}$ for $2 \mathrm{~min}$, and then increased by $2^{\circ} \mathrm{C} / \mathrm{min}$ to $215^{\circ} \mathrm{C}$. Identification of the major peaks was made by comparison with the retention times of known standards and by mass spectroscopy. The growth medium without any bacterial culture was processed in the same way and found to yield no significant peaks.

Electronmicroscopy. Biopsy tissue fragments for ultrastructural study were fixed by immersion in glutaraldehyde $2.5 \%$ in $0.1 \mathrm{M}$ sodium cacodylate buffer, $p \mathrm{H} 7 \cdot 2$, for at least $2 \mathrm{~h}$ (sometimes overnight) at $4^{\circ} \mathrm{C}$; they were then sliced carefully with a razor blade to facilitate orientation, washed twice in cacodylate buffer and post-fixed for $1 \mathrm{~h}$ in osmium tetroxide $1 \% \mathrm{w} / \mathrm{v}$ solution. Specimens were dehydrated and embedded in epoxy resin in the usual manner and thin sections were mounted on bare grids. Sections were stained either by the standard sequential method of saturated aqueous uranyl acetate for $1 \mathrm{~h}$ followed by lead citrate, $p \mathrm{H} \mathrm{12}$, for $5 \mathrm{~min}$ (Reynolds, 1963), or by a modified procedure that gave significant enhancement of bacterial image contrast. The sections were given a preliminary treatment with uranyl acetate $20 \% \mathrm{w} / \mathrm{v}$ in nitric acid $5 \%$ for $30 \mathrm{~min}$, followed by rinsing in distilled water for $1 \mathrm{~min}$ and staining by the standard uranyl acetate-lead citrate sequence as above.

For negative contrast, study organisms were obtained from the culture media and suspended in glucose $10 \% \mathrm{w} / \mathrm{v}$ solution. Carbon-coated grids were floated for $1-2 \mathrm{~min}$ on drops of the suspension, and then transferred for about $1 \mathrm{~min}$ to a drop of either aqueous potassium 


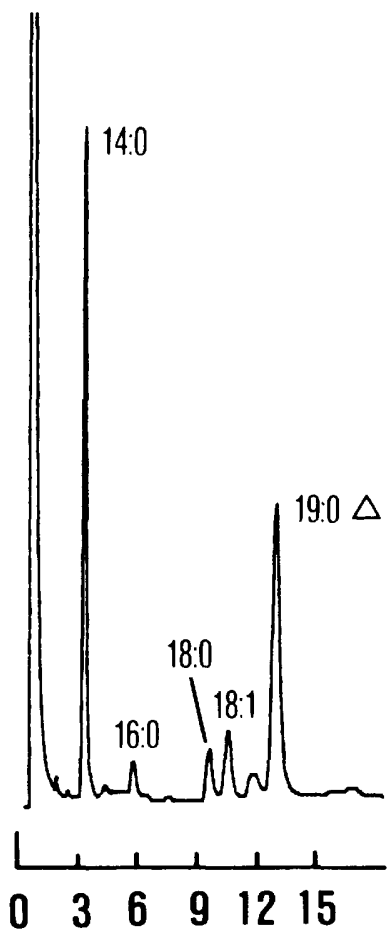

\section{Minutes}

FIG. 1.-Gas liquid chromatograph profile of cellular fatty acid methyl esters of $C$. pyloridis strain NCTC11637.

TABLE

Cellular fatty acid composition of 14 isolates of C. pyloridis

\begin{tabular}{l|ccccccc}
\hline & \multicolumn{7}{|c}{ Fatty acid* indicated as percentage } \\
of total fatty acids $\dagger$ \\
\cline { 2 - 8 } Isolate number & $14: 0$ & $16: 0$ & $18: 0$ & $18: 1$ & $18: 2$ & $19: 0 \Delta$ & $3-$ OH-16:0 \\
\hline Q1 & 45 & 2 & 4 & 11 & 2 & 30 & 3 \\
Q2 & 40 & 3 & 9 & 17 & 2 & 25 & 5 \\
Q3-NCTC 11638 & 41 & 3 & 6 & 14 & 3 & 28 & 4 \\
Q4-NCTC 11637 & 36 & 3 & 6 & 8 & 5 & 35 & 2 \\
Q5 & 31 & 4 & 9 & 20 & 3 & 28 & 4 \\
Q6 & 32 & 4 & 9 & 13 & 7 & 28 & 4 \\
Q11 & 31 & 3 & 10 & 20 & 4 & 29 & 3 \\
Q13 & 30 & 5 & 10 & 14 & 6 & 30 & 5 \\
Q14 & 33 & 3 & 10 & 19 & 3 & 24 & 5 \\
Q15 & 30 & 3 & 13 & 14 & 2 & 28 & 5 \\
Q21 & 42 & 4 & 8 & 7 & 3 & 28 & 4 \\
J14 & 34 & 3 & 10 & 12 & 3 & 30 & 5 \\
L25 & 33 & 5 & 11 & 14 & 6 & 21 & 6 \\
L26 & 33 & 7 & 10 & 8 & 4 & 29 & 3 \\
Mean & $35 \cdot 1$ & $3 \cdot 7$ & $8 \cdot 9$ & $13 \cdot 6$ & $3 \cdot 7$ & $28 \cdot 1$ & $4 \cdot 1$ \\
Range & $30-45$ & $2-7$ & $4-13$ & $7-20$ & $2-7$ & $21-35$ & $3-6$ \\
\hline
\end{tabular}

$\Delta$ Indicates cyclopropane ring.

* Number preceding colon denotes number of carbon atoms; number following colon denotes number of double bonds.

$\dagger$ Peaks with less than $2 \%$ were not recorded; all isolates contained trace amounts of 12:0,13:0 and 15:0. 
phosphotungstate $2 \% \mathrm{w} / \mathrm{v}, \mathrm{pH} 6 \cdot 8$, or ammonium molybdate $3 \% \mathrm{w} / \mathrm{v}, p \mathrm{H} 6 \cdot 5$. Occasionally suspensions were first fixed overnight by dilution with cacodylate-buffered glutaraldehyde $2.5 \%$,

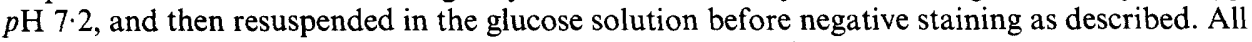
specimens were examined with a Philips EM 410 electronmicroscope.

\section{RESULTS}

\section{Cellular fatty acids of $C$. pyloridis}

The fatty acid methyl esters derived from acid-catalysed transmethylation of whole cells of $C$. pyloridis strain NCTC1 1637 are shown in fig. 1. The peak area integer values of the cellular fatty acid methyl esters for 14 isolates of $C$. pyloridis are shown in the table. High percentages of tetradecanoic (14:0) and cis-9,10-methyleneoctadecanoic $(19: 0 \Delta)$ acids were found in all isolates of $C$. pyloridis. Significant amounts of octadecenoic (18:1) and octadecanoic (18.0) acids were also found. The fatty acid methyl ester profile of an isolate of $C$. jejuni prepared under identical conditions is shown in fig. 2. This is within the range of previous reports of $C$. jejuni (McCoy et al., 1975; Curtis, 1983). It can be seen that the major cellular fatty acid of $C$. jejuni is hexadecanoic acid $(16: 0)$.

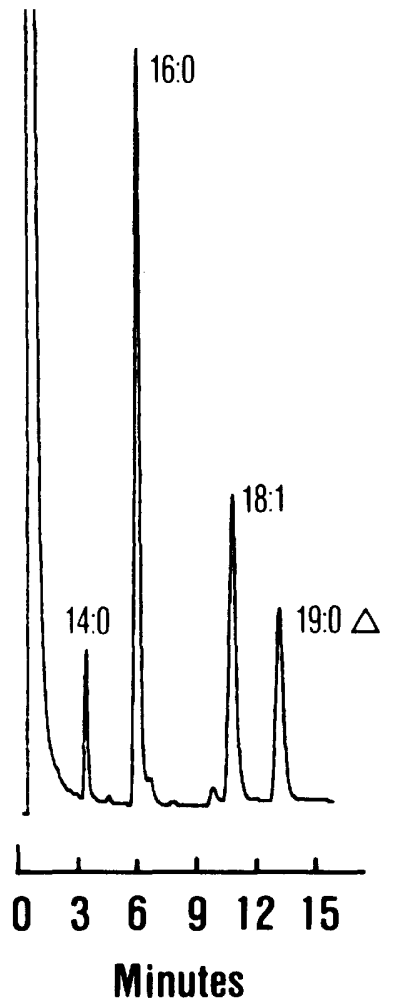

FIG. 2.-Gas liquid chromatograph profile of cellular fatty acid methyl esters of an isolate of C. jejuni. 


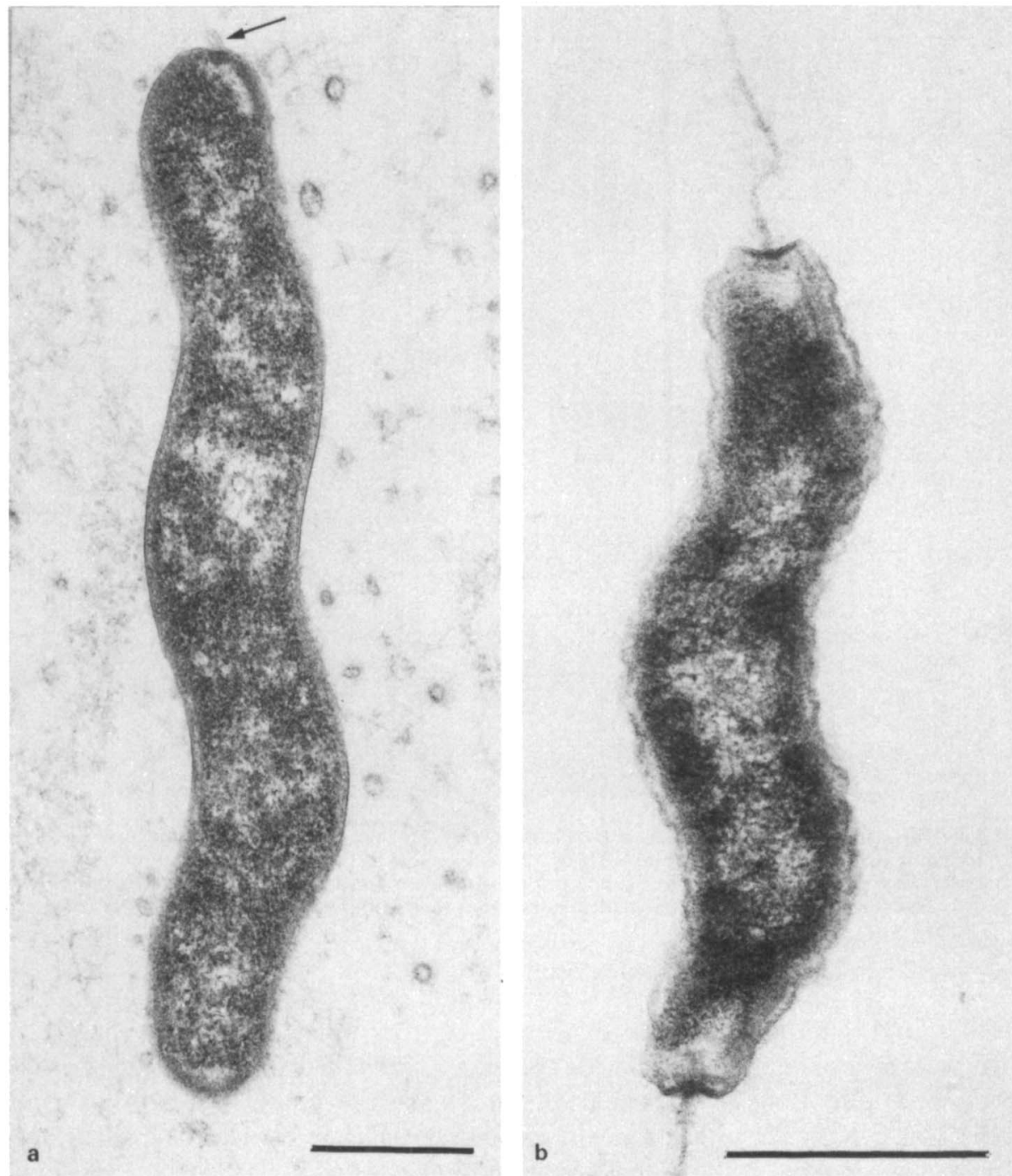

FIG. 3-- a. Longitudinal thin-section of a spiral gastritis-associated bacterium ( $C$. pyloridis) as seen in a gastric biopsy, showing the general ultrastructural appearance. Note the smooth bacterial surface and bluntly rounded ends. A single sheathed flagellum (arrow) is featured here. (Bar $=500 \mathrm{~nm}$ ). b. Longitudinal thin-section of $C$. jejuni showing the typical rugose cell wall, polar pits, and unsheathed bipolar flagella. (Bar $=500 \mathrm{~nm})$.

\section{Ultrastructural appearances}

Thin-section micrographs of gastric antral mucosal biopsies showed the organism located beneath the layer of gastric mucus and in close proximity to the luminal surfaces of the mucus secreting epithelial cells, reaching also for a short distance into the glandular pits. Where bacteria were numerous the mucus cells showed irregular surface bulging with depletion or loss of microvilli but exhibited no other obvious cytopathic features. The bacteria appeared as flagellate curved rods, or S-shaped 


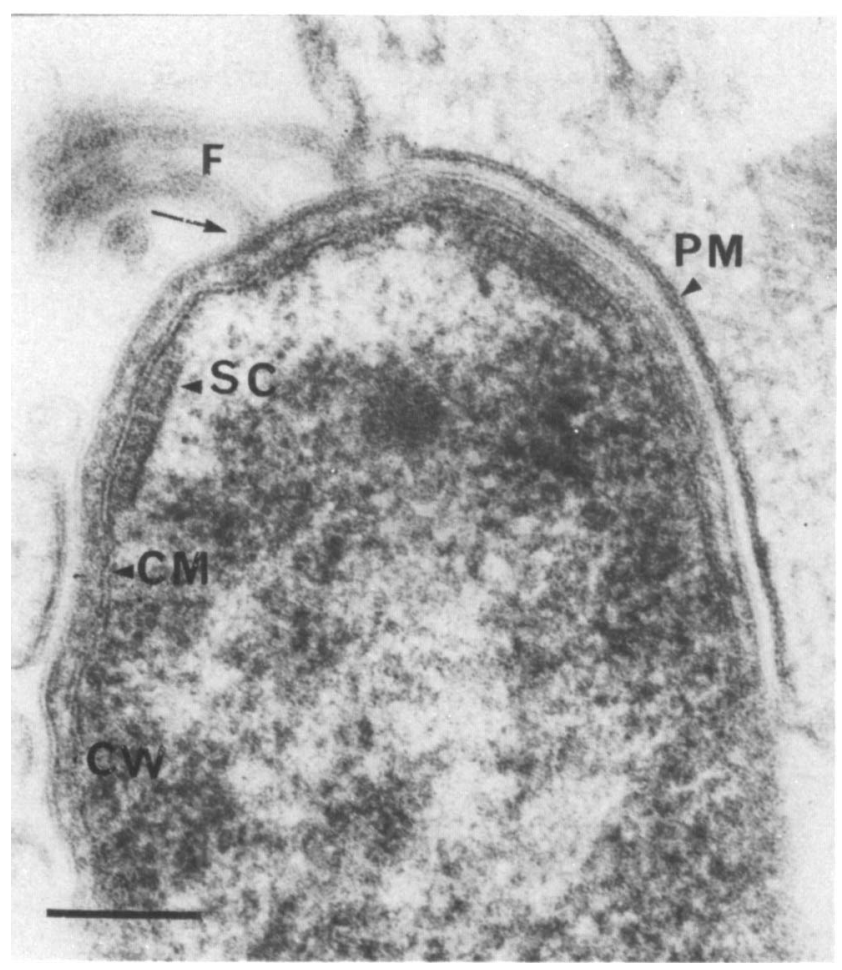

FIG. 4.-Thin-section micrograph from an antral biopsy showing the flagellar pole of $C$. pyloridis in intimate contact with the plasma membrane (PM) of a mucus secreting epithelial cell. Relationships of the cell wall $(\mathrm{CW})$, cytoplasmic membrane (CM) and the submembranous complex (SC) are described in the text. Two flagella are sectioned $(\mathrm{F})$, with apparent continuity of the sheath with the cell wall membrane (arrow). (Bar=100 $\mathrm{nm})$.

profiles, with bluntly rounded ends without obvious polar depressions (figs. 3a, 4). They were approximately $0.5 \mu \mathrm{m}$ wide and were usually up to $3 \mu \mathrm{m}$ in length but longer forms were also seen. The external cell wall was smooth and closely followed the underlying cytoplasmic membrane, in contrast to the characteristic rugose surface of C. jejuni (fig. 3b). Fig. 4 shows the flagellar pole of a gastritis-associated organism that has made intimate contact with the plasma membrane (PM) of a mucus lining epithelial cell. The bacterial cell wall (CW) and cytoplasmic membrane (CM) are closely adherent, with traces of intervening flocculent electron-opaque material suggestive of a mucopeptide layer. A honeycomb-like thickening or submembranous complex (SC), is present beneath the cytoplasmic membrane on each side of the flagellar attachment site. In negatively stained preparations the organisms showed multiple flagella, 4-6 in number, arising from one pole of the cell (fig. 5a); examples of bipolar flagellation were seen only occasionally, notably in dividing organisms. The flagella measured c. $30 \mathrm{~nm}$ in external diameter; they were invariably sheathed and contained a core-like shaft $c .12 \mathrm{~nm}$ in thickness. The proximal termination of the flagellar core is in a basal disc (BD) apparently associated with the bacterial cytoplasmic membrane. Negative stain images suggesting penetration of the cell wall by the flagellar sheath (as in fig. 5a) are due to cell-wall overlap within the dried 

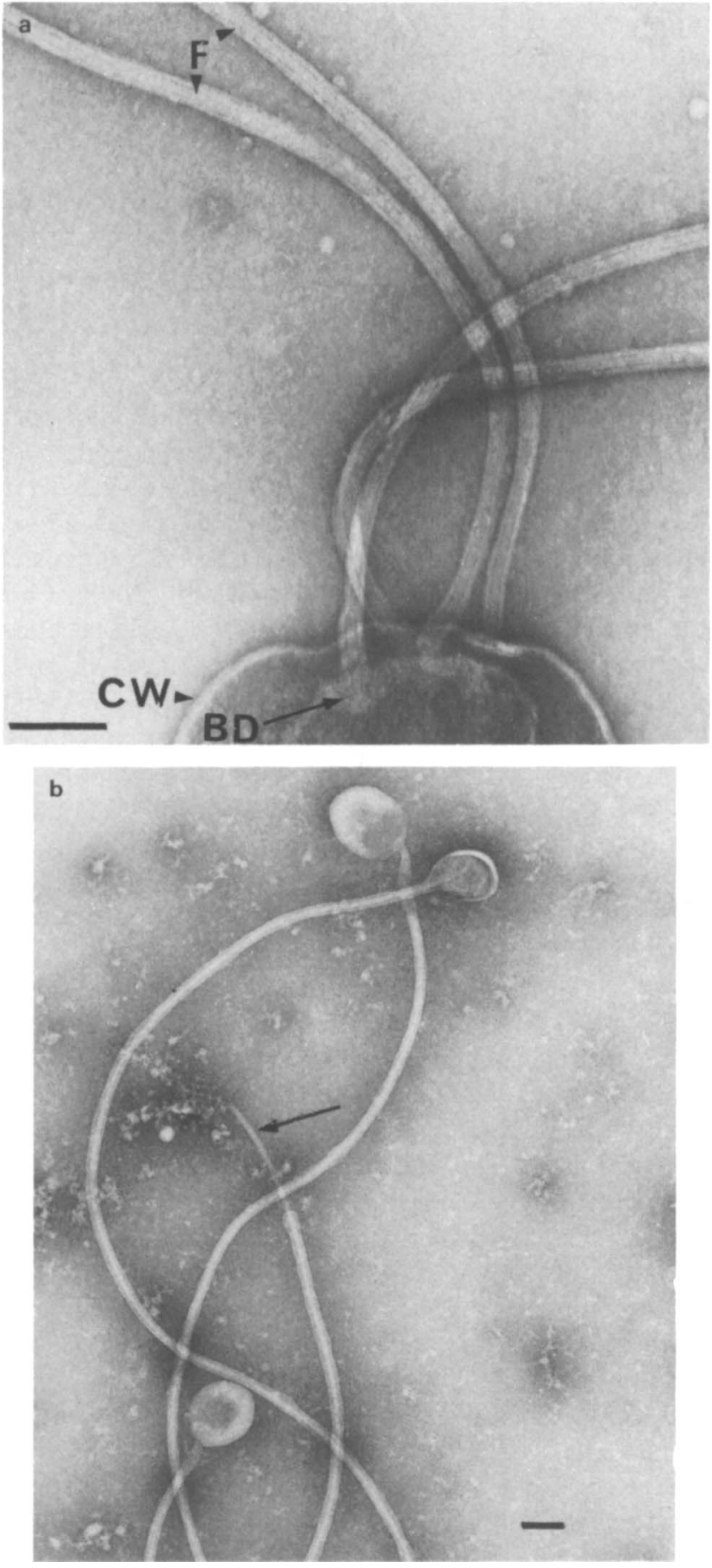

FIG. 5.-Negative contrast micrographs: a - proximal extremity of typical C. pyloridis flagella showing the sheathed character of four polar flagella (F) and termination of the core in a basal disc (BD); $b-$ the distal ends of three flagella showing typical terminal bulbs; arrowed is the protruding core of a fourth flagellum presumably ruptured during processing. Negative stain: $3 \%$ ammonium molybdate, $p \mathrm{H} 6 \cdot 5$. $($ Bars $=100 \mathrm{~nm})$. 
specimen on the grid. In sectioned specimens it was often possible to discern continuity of flagellar sheaths with the unit membrane of the outer cell wall (fig. 4). A round or ovoid terminal bulb was present at each flagellar tip. Three intact flagellar terminal bulbs are seen in fig. $5 \mathrm{~b}$; the fourth flagellum was evidently ruptured in processing, with resulting sheath retraction and partial exposure of the inner core. These terminal bulbs were regularly present in glutaraldehyde-fixed thin sections as well as in unfixed and glutaraldehyde pre-fixed negative contrast specimens and, therefore, seem unlikely to be artefacts, although they appear fragile and subject to distortion or breakage.

\section{Discussion}

Difficulties arise in assigning the spiral bacteria from the gastric mucosa $(C$. pyloridis) to either of the familiar genera of spiral bacteria, namely Spirillum and Campylobacter Vibrio spp. can also assume a spiral form (Tweedy et al., 1968). These genera are distinct from the true spirochaetes (Hovind-Hougen, 1976), which include the human rectal spirochaete (Hovind-Hougen et al., 1982); and also from a recently described spiral organism from the gut of rodents (Phillips and Lee, 1983). Spirochaetes and the rodent organism exhibit morphological peculiarities, including endoflagella or periplasmic fibres, and bear little resemblance to $C$. pyloridis. Spirillum spp. have a DNA base composition of guanosine plus cytosine $38-63 \mathrm{~mol} \%$, Vibrio spp. G $+\mathrm{C} 45-50 \mathrm{~mol} \%$ (Buchanan and Gibbons, 1974), and Campylobacter spp. $\mathrm{G}+\mathrm{C} 32-38 \mathrm{~mol} \%$ (Tanner et al., 1981). Analyses of $C$. pyloridis have yielded a DNA base composition of $\mathrm{G}+\mathrm{C} 35 \cdot 8-37 \cdot 1 \mathrm{~mol} \%$ (Marshall et al., 1984), which is within the Campylobacter range.

At present the definition of Campylobacter relies on only a few characters, in particular $\mathrm{G}+\mathrm{C}$ mol \% content of DNA, their spiral appearance, and respiratory requirements (Véron and Chatelain, 1973; Smibert, 1981). Additionally campylobacters have been shown to have a similar isoprenoid composition (Collins et al., 1984). In our study we have shown that the cellular fatty acids of $C$. pyloridis are markedly different from those of other Campylobacter spp. whose major fatty acids are 16:0, 18:1 and 16:1 (Tornabene and Ogg, 1971; Smibert, 1978; Blaser et al., 1980; Leaper and Owen, 1981; Curtis, 1983). In contrast C. pyloridis contains high percentages of $14: 0$ and 19:0 $\Delta$, and significant amounts of 18:1 and 18:0. This profile is also in marked contrast to Spirillum spp. and Vibrio spp., whose major fatty acids are 16:1, 16:0 and 18:1 (Curtis, 1983; Lambert et al., 1983); 19:0 $\Delta$ was not found in either of these genera. The major fatty acids of other enterobacteria are also 16:0 and 16:1 with moderate amounts of 14:0 and 18:1 (Bøe and Gjerde, 1980; Lambert et al., 1983). Thus the major cellular fatty acids of $C$. pyloridis are different from those of any other known enterobacteria, including Campylobacter spp.

In this study we have used acid-catalysed transmethylation of whole cells under very mild conditions to determine the fatty-acid profiles. This method is simple, gives good reproducibility and yields, and does not lead to any apparent degradation of cyclopropyl fatty acids - a problem associated with other methods based on acid hydrolysis (Lambert and Moss, 1983).

Ultastructurally, C. pyloridis has a smooth cell surface at variance with the loose or "rugose" cell walls of Campylobacter spp. so far described (Ritchie et al., 1966; Pead, 1979). The flagellar pattern of $C$. pyloridis differs from that reported for $C$.fetus and $C$. 
jejuni in which, typically, a single unsheathed flagellum arises from a distinct pit-like depression at both poles of the spiral organism (Ritchie et al., 1966; McCoy et al., 1975; Pead, 1979), although aberrant forms with more flagella sometimes occur in cultures (Ritchie et al., 1966). Absence of flagellar sheathing has, indeed, been advanced in support of the generic separation of campylobacters from the genus Vibrio (McCoy et al., 1975). In contrast, sheathed flagella are amply documented in Vibrio (Follett and Gordon, 1963; Glauert et al., 1963), pseudomonads (Fuerst and Hayward, 1969), and Spirillum (Lockard and Boler, 1968). Terminal bulbs similar to those of C. pyloridis have also been noted on the sheathed flagella of $V$. cholerae (Rowles et al., 1976). It would appear that the flagellar apparatus of $C$. pyloridis, as reported here, is without parallel among other campylobacters so far studied in detail; indeed the flagella more closely resemble those reported for several vibrios.

Sections of $C$. pyloridis have revealed a localised honeycomb-like submembranous complex associated with the cytoplasmic membrane, apparently encircling the organism near the flagellate pole. Corresponding structural specialisations are, however, present in a wide spectrum of flagellate bacteria including Spirillum spp. (Murray and Birch-Anderson, 1963), campylobacters (McCoy et al., 1975) and several vibrios (Vaituzis and Doetsch, 1969; Rowles et al., 1976). Their presence may therefore prove of limited value as a guide to the taxonomic placement of $C$. pyloridis.

As a result of our studies we suggest either that $C$. pyloridis can be regarded as an unusual or atypical member of the genus Campylobacter, the limits of which may have to be redefined to accommodate the new species or, as is more likely, that it may prove necessary to assign this interesting organism from the human stomach to another known genus or even to a new genus; but such developments must await further detailed studies including DNA hybridisation.

We thank Dr T. Waters and Dr C. Sanderson for obtaining the endoscopic biopsies, and Dr D. I. Annear, Miss J. Burton, and Mrs E. Blincow for technical assistance. This work was supported in part by the Research Foundation of the Royal Perth Hospital, Western Australia.

\section{REFERENCES}

Blaser M J, Moss C W, Weaver R E 1980 Cellular fatty acid composition of Campylobacter fetus. Journal of Clinical Microbiology 11:448-451.

Bøe B, Gjerde J 1980 Fatty acid patterns in the classification of some representatives of the families Enterobacteriaceae and Vibrionaceae. Journal of General Microbiology 116:41-49.

Buchanan R E, Gibbons N E 1974 Bergey's Manual of Determinative Bacteriology, 8th edn. Williams and Wilkins, Baltimore, pp 197, 340.

Collins M D, Costas M, Owen R J 1984 Isoprenoid quinone composition of representatives of the genus Campylobacter. Archives of Microbiology 137:168-170.

Curtis M A 1983 Cellular fatty acid profiles of campylobacters. Medical Laboratory Sciences 40:333-348.

Eldridge J, Lessells A M, Jones D M 1984 Antibody to spiral organisms on gastric mucosa. Lancet 1:1237.

Follett E A C, Gordon J 1963 An electron microscope study of vibrio flagella. Journal of General Microbiology 32:235-239.

Fuerst J A, Hayward A C 1969 The sheathed flagellum of Pseudomonas stizolobili. Journal of General Microbiology 58:239-245.

Glauert A M, Kerridge D, Horne R W 1963 The fine structure and mode of attachment of the sheathed flagellum of Vibrio metchnikovii. Journal of Cell Biology 18:327-336. 
Hovind-Hougen K 1976 Determination by means of electron microscopy of morphological criteria of value for classifications of some spirochaetes, in particular treponemes. Acta Pathologica et Microbiologica Scandinavica Section B, Supplement no. 255:20-22.

Hovind-Hougen K, Birch-Andersen A, Henrik-Nielsen R, Ornholm M, Pedersen J O, Teglbjaerg P S, Thaysen E H 1982 Intestinal spirochetosis: Morphological characterization and cultivation of the spirochaete Brachyspira aalborgi gen. nov., sp. nov. Journal of Clinical Microbiology 16:1127-1136.

Lambert M A, Hickman-Brenner F W, Farmer J J, Moss C W 1983 Differentiation of Vibrionaceae species by their cellular fatty acid composition. International Journal Systematic Bacteriology 33:777-791.

Lambert M A, Moss C W 1983 Comparison of the effects of acid and base hydrolyses on hydroxy and cyclopropane fatty acids in bacteria. Journal of Clinical Microbiology 18:1370-1377.

Leaper S, Owen R J 1981 Identification of catalase-producing Campylobacter species based on biochemical characteristics and on cellular fatty acid composition. Current Microbiology 6:31-35.

Lechevalier M P 1977 Lipids in bacterial taxonomy-a taxonomist's view. CRC Critical Reviews of Microbiology 5:109-210.

Lockard V G, Boler R K 1968 Ultrastructure of spirilla found in the gastric mucosa of dogs. Journal of Cell Biology 39:82a.

Marshall B J 1983 Unidentified curved bacilli on gastric epithelium in active chronic gastritis. Lancet 1:1273-1275.

Marshall B J, Royce H, Annear D I, Goodwin C S, Pearman J W, Warren J R, Armstrong J A 1984 Original isolation of Campylobacter pyloridis from human gastric mucosa. Microbios Letters 25:83-88.

Marshall B J, Warren J R 1984 Unidentified curved bacilli in the stomach of patients with gastritis and peptic ulceration. Lancet 1:1311-1314.

McCoy E C, Doyle D, Wiltberger H, Burda K, Winter A J 1975 Flagellar ultrastructure and flagella-associated antigens of Campylobacter fetus. Journal of Bacteriology 122:307-315.

McNulty C A M, Watson D M 1984 Spiral bacteria of the gastric antrum. Lancet 1:1068-1069.

Murray R G E, Birch-Andersen A 1963 Specialized structure in the region of the flagella tuft in Spirillum serpens. Canadian Journal of Microbiology 9:393-402.

Pead P J 1979 Electron microscopy of Campylobacter jejuni. Journal of Medical Microbiology 12:383-385.

Phillips M W, Lee A 1983 Isolation and characterization of a spiral bacterium from the crypts of rodent gastrointestinal tracts. Applied and Environmental Microbiology 45:675-683.

Reynolds E S 1963 The use of lead citrate at high $p \mathrm{H}$ as an electron-opaque stain in electron microscopy. Journal of Cell Biology 17:208-213.

Ritchie A E, Keeler R F, Bryner J H 1966 Anatomical features of Vibrio fetus; electron microscopic survey. Journal of General Microbiology 43:427-438.

Rollason T P, Stone J, Rhodes J M 1984 Spiral organisms in endoscopic biopsies of the human stomach. Journal of Clinical Pathology 37:23-26.

Rowles C R, Parton R, Jeynes M H 1976 Some aspects of the cell walls of Vibrio spp. In: Fuller R, Lovelock D W (eds) Microbial ultrastructure. Academic Press, London, pp 109-115.

Smibert R M 1978 The genus Campylobacter. Annual Review of Microbiology 32:673-709.

Smibert R M 1981 Genus Campylobacter. In: Starr M P et al. (eds) The prokaryotes. A Handbook on habitats, isolation and identification of bacteria, vol. 1. Springer Verlag, Berlin, pp 609-617.

Tanner A C R, Badger S, Lai S H, Listgarten M A, Visconti R A, Socransky S S 1981 Wolinella gen. nov., Wolinella succinogenes (Vibrio succinogenes Wolin et al.) comb. nov., and description of Bacteroides gracilis sp. nov., Wolinella recta sp. nov., Campylobacter concisus sp. nov., and Eikenella corrodens from humans with periodontal disease. International Journal of Systematic Bacteriology 31: 432-445.

Tornabene T G, Ogg J E 1971 Chromatographic studies of the lipid components of Vibrio fetus. Biochimica et Biophysica Acta 239:133-141.

Tweedy J M, Park R W A, Hodgkiss W 1968 Evidence for the presence of fimbriae (pili) on Vibrio species. Journal of General Microbiology 51:235-244. 
Vaituzis Z, Doetsch R N 1969 Relationship between cell wall, cytoplasmic membrane and bacterial motility. Journal of Bacteriology 100:512-521.

Véron M, Chatelain R 1973 Taxonomic study of the genus Campylobacter Sebald and Véron and designation of neotype strain for the type species Campylobacter fetus (Smith and Taylor) Sebald and Véron. International Journal of Systemic Bacteriology 23:122-124.

Warren J R 1983 Unidentified curved bacilli on gastric epithelium in active chronic gastritis. Lancet 1:1273. 